\title{
MOBILE APPS OF SPANISH TALK RADIO STATIONS. ANALYSIS OF SER, RADIO NACIONAL, COPE AND ONDA CERO'S PROPOSALS
}

Las aplicaciones móviles de las emisoras generalistas en España: análisis de las propuestas de SER, Radio Nacional, COPE y Onda Cero

Susana Herrera-Damas y Eva-María Ferreras-Rodríguez

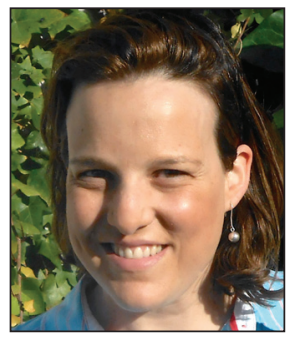

Susana Herrera-Damas holds a PhD in audiovisual communication and is a journalism professor at the Universidad Carlos III de Madrid. Her research is focused on journalistic ethics, radio narrative and on how social media can increase the technical and ethical quality of journalism. http://orcid.org/0000-0002-1755-1621

Universidad Carlos III de Madrid, Departamento de Periodismo y Comunicación Audiovisual C/ Madrid, 133.28903 Getafe, Madrid, España dherrera@hum.uc3m.es

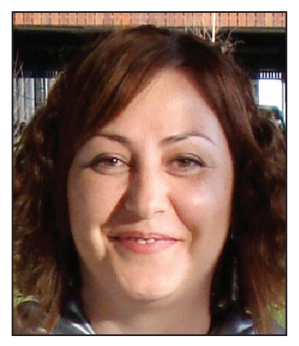

Eva-María Ferreras-Rodríguez, an independent researcher, holds a PhD in journalism. Her studies focus mainly on the new dynamics of social communication networks and their relationship with the media.

https://www.linkedin.com/pub/eva-m\%C2\%AA-ferreras-rodr\%C3\%ADguez/1a/991/1aa http://orcid.org/0000-0002-8604-034X

eva.ferreras@gmail.com

\section{Abstract}

Mobile devices today have become the center of our connectivity. Radio companies tailor their content in several ways: podcasting, streaming, and mobile applications. The aim of this paper is to learn more about the mobile app content of the most popular talk radio stations in Spain. For this purpose, in January 2015 we conducted a qualitative content analysis in order to establish the type of products provided, their structure and hierarchy, and to determine to what extent Spanish talk radio stations are taking full advantage of this new potential.

\section{Keywords}

Apps; Mobile; Mobile applications; Radio; Radio stations; Content; Tablets; Smartphones; Spain.

\section{Resumen}

Hoy, los dispositivos móviles se han convertido en el centro de nuestra conectividad. Las empresas radiofónicas tratan de adaptar sus contenidos de distintas maneras: a través del podcasting, del streaming y de las aplicaciones móviles. El propósito de este artículo es conocer más el contenido que las emisoras de radio generalistas españolas están ofreciendo a través de sus aplicaciones móviles. Para ello en enero de 2015 hemos llevado a cabo un análisis cualitativo. Además de los contenidos se ha estudiado su estructura, jerarquía y hasta qué punto están aprovechando todo este nuevo potencial. Se espera además que el instrumento de análisis resulte de utilidad para otras investigaciones que analicen la oferta de apps de perfil periodístico.

\section{Palabras clave}

Apps; Aplicaciones móviles; Móvil; Radio; Emisoras de radio; Contenidos; Tablets; Smartphones; España.

Herrera-Damas, Susana; Ferreras-Rodríguez, Eva-María (2015). "Mobile apps of Spanish talk radio stations. Analysis of SER, Radio Nacional, COPE and Onda Cero's proposals". El profesional de la información, v. 24, n. 3, pp. $274-281$. 


\section{Introduction}

The increase in the use of mobile devices (3G/4G) and the resulting growth in the possibilities for mobility have opened alternative channels for distribution of media content. This has led many media industries to develop their apps for these devices to have a presence in these spaces. The aim of this article is to analyze the apps for smartphones and tablets provided by Spanish talk radio stations. From a more focused point of view, we want to learn more about their structure, the kind of content they offer, their usability, the possibilities for personalization and participation, as well as any additional services they provide. In order to do so, we conducted a qualitative content analysis of the main Spanish talk radio stations' apps. The analysis -conducted during the last two weeks of January, 2015- consisted of reviewing the frequency of occurrence from the different functionalities included in our analysis code. These functionalities referred to aspects related to the structure, design, content, usability, customization, participation, and additional services offered in these apps. Before presenting the results, we advance some brief notes about the theoretical construct on which our research is based.

2. The mobile Internet as the new media ecosystem

The rapid development in new technologies for connection

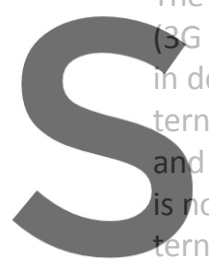
and mobile broadband) devices have benefitted the in rnet, which has spread very av social penetration has incre longer exclusively through

mobile devices. In fact, since 2008 , use of mobile broadband, Register for free at httpadpand has increased In 2010 , the

2011 by 40\% (Fundación Telefónica, 2013, pp. 33). During 2014, 2,315 mobile internet access subscribers have been established worldwide. In this case the growth is $20 \%$, mainly in the emerging markets (Fundación Telefónica, 2014, p. 30).

In Spain, the evolution is similar, with mobile broadband use rising over the past several years. According to the Society of information Report (Fundación Telefónica, 2014, p. 36), in the first quarter of 201470.4 out of 100 use mobile broadband, with an increase of $26.6 \%$ with respect to the same quarter of the previous year.

The diversification, in terms of how people access the Internet, fostered by improvements in mobile devices and also in technologies, has encouraged the evolution of the mobile Internet. In this context, mobility challenges the media industries, forcing them to look for new scenarios for adaption. One of the main activities carried out on a mobile device is reading the news and accessing legacy media; at the same time, users demand more personalized information. As a result the media industry feels compelled to modify their traditional models to adapt themselves to this new mobility context. This is why many media outlets are currently working to design multiplatform strategies (Chyi; Chadha, 2012, p. 432).
Obviously, radio is also affected by all these changes. With the arrival of the Internet, radio is able to incorporate new services, content, and features beyond audio, including texts, images, videos, galleries, and live program streaming. Today radio websites provide content through streaming and podcasts that can be downloaded anytime, increasing the possibilities of retrieving, interacting with, and personalizing content. The resulting transformation of this "mediamorphosis" (Fidler, 1997, p. 37) has given birth to a new scenario that Cebrián-Herreros (2009, p. 21) has coined "cyberradio". Ortiz-Sobrino (2012, p. 8) uses the term "postradio" to describe a new paradigm in which radio is a hybrid system for multimedia content distribution, made possible by the combination of the Internet and mobile technology. The next stage of development will rely precisely in its mobility through these devices.

\section{With the arrival of the Internet, it is pos- sible to incorporate to radio new servi- ces, content, and features beyond audio including texts, images, videos, galleries, and live program streaming}

On the other hand, the adaption of media content to this

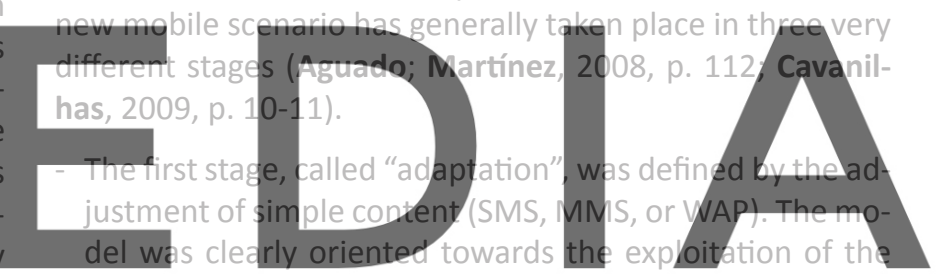

new platform as an added value that was strongly linked

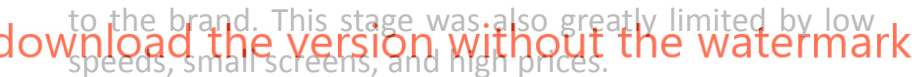
rise to the second phase, called the "autonomy stage", where media industries started to design adapted strategies and created more optimized versions of their websites for mobile phones.

- As $3 G$ technology and its social assimilation advances, along with the popularization of smartphones and tablets, a third stage has emerged. This phase, called "emancipation", is defined by the development of autonomous applications that allow access to informative content of a multimedia nature.

Logically, this is the ideal stage for any app development. Referring to radio apps, Videla-Rodríguez and Piñeiro-Otero (2013a) agree with Cebrián-Herreros (2008) when stating that mobile radio demands a redesign for mobile access, particularly for the applications used for always and everywhere access:

"As The horizon report 2012 states, the best applications are those that are fully adapted to the potential of the device itself, using positioning data, motion detection, access to social networks or web search -among otherswithin a complete and enriched experience" (VidelaRodríguez; Piñeiro-Otero, 2013a). 


\section{Mobile devices as new tools for multimedia convergence}

Mobile devices have become the leading tools for multimedia convergence. They also modify the way users produce and consume news. The technological convergence of mobile phones and multimedia began in the 90s, but popularization took much longer. As Westlund $(2013$, p. 6) suggests, in the social assimilation of these devices several mobile features have played a role; first, the functionalities offered -cameras, GPS services, touchscreens, social networks services, etc.-; second, the price reduction in the flat rates and the massive sales of smartphones and tablets. Thus, the use of mobile services began to spread when these features became available (Nel; Westlund, 2012, p. 744).

In the evolution of the mobile devices market, the appearance of the iPhone in 2007 was pivotal. According to the Gartner figures for the $3^{\text {rd }}$ quarter of 2014, the sales of smartphones increased by $30.2 \%$ (301 million units till the end of September).

\section{Mobile devices have become the leading tools for multimedia convergence while apps present an opportunity to relaunch radio content and to increase its social}

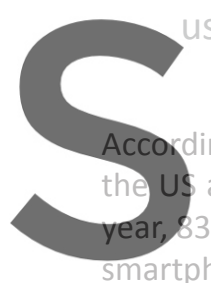
use
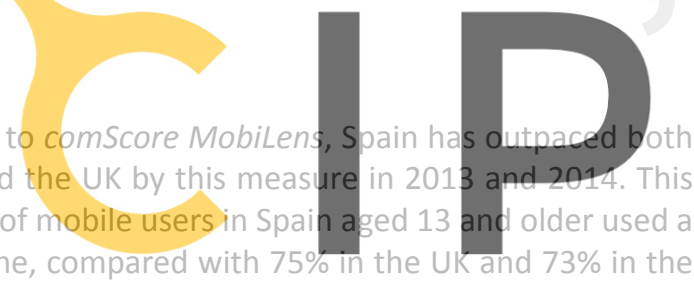

US. What's more, Spain already registers one of the highest

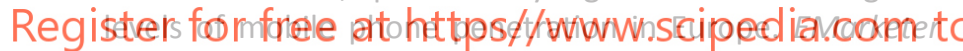
estimates that $85.4 \%$ of the entire population will use a mobile phone this year.

http://www.emarketer.com/Article/Smartphones-RuleSpain/1011558

As for tablets, according to a recent study by Gartner, the number sold during 2012 and 2013 raised 55\%. In fact, the company estimates that the technological panorama will drastically change in the upcoming years. Traditional laptops will be pushed into the background as opposed to tablets, which will become the leading competitors in the market. In Spain, the presence of tablets is $14 \%$, twice the European average. Their use increased $500 \%$ in 2012, although they are used by only $2.7 \%$ of Internet users. The number of tablets in Spain is estimated to be around 2.2 million (Fundación Telefónica, Society of information report, 2013, p. 52). http://www.gartner.com/newsroom/id/2408515

In this context, the mobile Internet is a new media ecosystem defined by its connectivity, immediacy, portability, personalization, and ubiquity. According to Aguado and Martínez $(2008$, p. 110) these characteristics turn out to be their main appeal for media industries' involvement. In the case of radio, it can be streamed through multimedia receptors, smartphones, tablets, and other types of digital receptors
(Del-Bianco, 2010). According to Videla-Rodríguez and Piñeiro-Otero (2013a), this multiplication of everywhere receptors has led Arbitron (2012) to refer to it as "the radio without limits".

\section{Apps as new structures for content distribution}

Mobile apps can be defined as computer systems developed specifically to work on mobile devices, offering several various functionalities and services to their users. In 2008 and at the same time as the launch of the iPhone 3G, Apple inaugurated its App Store. In the beginning, it offered 500 apps. In 2010, the arrival of the iPad also contributed to the increase in the number of apps and also in downloads. Regarding the number of apps available at the App Store there are over 1.4 million. This figure demonstrates the dramatic increase that has taken place in this market.

Accordingly, the 'app store' model has also been introduced by competitors, such as Google for its Android system. In 2014, the Google Play Store had passed from 700,000 apps to more than 1.5 million according to the data provided in the appFigures report. Thereby apps have become new structures for content distribution in the mobile ecosystem. http://blog.appfigures.com/app-stores-growth-acceleratesin-2014

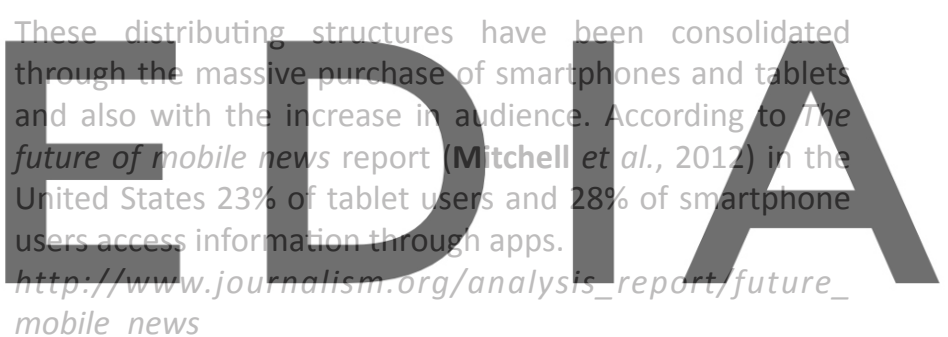

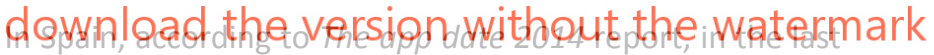
year the number of active app users has continued to rise. http://madrid. theappdate.com/vinformeestadoapps

Now, in 2015, there are nearly 23 million users while 3.8 million apps are downloaded daily. The apps related to information are $53.1 \%$ of the total. Android is the operative system used by half of the smartphone and tablet users, followed by iOS and the Windows Phone. With these figures, Android leads the number of downloads with 87 million compared with 24 from Apple. According to the abovementioned $A I M C$ report, $37 \%$ of those surveyed used an app to listen to the radio on mobile devices. Thus, apps have become one of the most flourishing markets in the mobile ecosystem. As many analysts predict, the increase in the number of apps and in the number of downloads will continue to rise in the future.

As seen, the rapid evolution of mobile devices has stimulated the development of cross-platform solutions for the distribution of radio content. In this context, apps present an opportunity to relaunch radio content and to increase its social use. Since 2011, several radio stations, including those selected for this study, have launched applications for mobile devices. Let us analyze what the top Spanish talk radio stations are offering in their apps for mobile devices. 

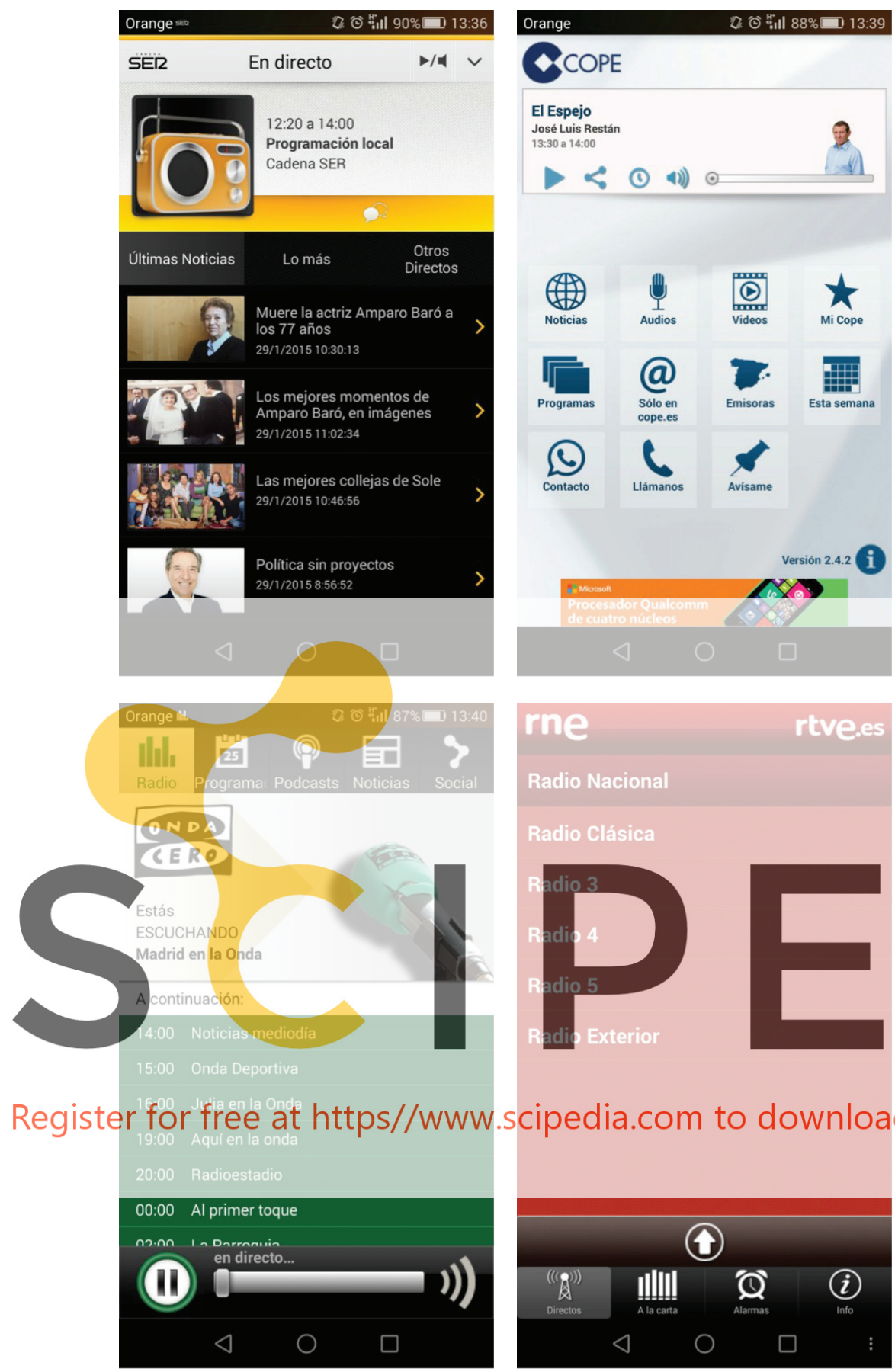

Figure 1. Screenshots from the analyzed apps

\section{Methodology}

First, we checked the mobile offerings of the most popular Spanish talk radio stations. A mobile presence attests to the interest of the stations in the mobile landscape. However, we maintain that the radio stations are not taking full advantage of the app format potential. Our starting hypotheses are:

H1) Spanish talk radio stations undervalue the potential of apps for mobile devices and they use them mostly as new channels for distribution and do not consider them autonomous and independent services.

$\mathrm{H} 2$ ) The mobile offerings provided by Spanish talk stations rarely include content that is strictly radio.
H3) Thus far, talk radio stations' apps seem to be mostly web-based, when considering both their design and content.

Since we could not find any previous code for radio apps, we reviewed the literature (Canavilhas, 2009; Arroyo-Vázquez, 2012; VidelaRodríguez; Piñeiro-Otero, 2012; Nozal-Cantarero; González-Neira, 2012) to proceed with our own proposal. In order to study the morphology of each app, our code takes into account different aspects such as its structure, content, usability, personalization, participation, and the offer of additional services.

\section{Results}

In all the cases, the apps are identical both for iOS (Apple) and for Android. All the stations allow live listening through their applications. Their covers present a menu divided into sections.

As can be seen in the pictures, SER, COPE, and Onda Cero open their cover with the program being broadcasted. Then, the menu is shown at the bottom of the screen with the various sections provided: news, podcasts, 'the most', programming, etc. In the three stations, the structure is divided into
two very different parts: i) the heading, whe-
re the icons of the program bein broadcas-
ted can be found; ii) the second part with the
news (Cadend SER), the upconing program-
ming (Onda Cero), and the different section with their corresponding icons (COPE), which

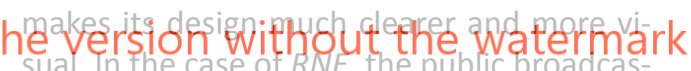

ter, it is necessary to choose among different channeis. in the menu at the bottom, there are four sections: live radio, personalized radio, alarms, and info. Data are summarized in table 1.

As for the content, all the apps include radio programming; the Radio 1 (Radio Nacional) app also offers the text of news items. Onda Cero and COPE also include news bulletins within their podcast section. All the stations allow listening or downloading entire programs or even small audio clips, as in Onda Cero. Cadena SER offers a section called "The most" where it collects some audio clips of the programs. Regarding other items, such as visuals or videos, pictures are included in the texts of many news items. The only two apps that offer a video section are the ones of COPE and Radio 1. Only Onda Cero and COPE provide the station profiles in Facebook and Twitter. Results are in line with those obtained by Videla-Rodríguez and Piñeiro-Otero (2013b) when analyzing the offer of 16 Spanish radio apps, including talk and specialized radio:

"A characteristic feature of the analyzed apps is its simplicity, particularly in the applications for iPhone and Android. Of all the possibilities that the language of web 
Table 1. Structure in the mobile Spanish talk radio stations' apps

\begin{tabular}{|l|l|l|l|l|l|}
\cline { 2 - 5 } \multicolumn{1}{c|}{} & \multicolumn{2}{c|}{ SER } & \multicolumn{1}{c|}{ RNE } & \multicolumn{1}{c|}{ COPE } & \multicolumn{1}{c|}{ OC } \\
\cline { 2 - 6 } & \multicolumn{1}{c|}{ Cadena SER logo } & RNE stations & Live radio/sections & Onda Cero logo \\
\hline Menus & Yes & Yes & Yes & Yes & Yadena COPE logo \\
\hline Sections & $\begin{array}{l}\text { Live, Stations, Pro- } \\
\text { gramming, Program- } \\
\text { mes, Last news }\end{array}$ & $\begin{array}{l}\text { News, Live, } \\
\text { A la carta, } \\
\text { Info }\end{array}$ & $\begin{array}{l}\text { News, Audios, Videos, My COPE, } \\
\text { Programmes, Only in Cope.es, } \\
\text { Stations, This week, Contact, } \\
\text { Call us, Notice me }\end{array}$ & $\begin{array}{l}\text { Radio, Programming, } \\
\text { Podcasts, News, Social }\end{array}$ & $\begin{array}{l}\text { Prows, Audios, Videos, My COPE, } \\
\text { tions, This week, Contact, Call us, } \\
\text { Notice me, Find other listeners }\end{array}$ \\
\hline
\end{tabular}

radio provides, most applications only offer audio and text content. Images are just limited to the ones of the application design (backgrounds, icons for programs and pictures of speakers)" (Videla-Rodríguez; PiñeiroOtero, 2013b, p. 99).

Regarding advertising content, we find banners in the apps of Cadena SER, COPE, and Onda Cero and also in the COPE app for iPad. These banners generally appear at the bottom when opening the application and also during the navigation.

As for usability, the clearest and most visual menu is that of the Cadena COPE app. In all the apps, changing the section can be carried out through the menu, and navigability is relatively easy because content is vertically structured.

Results are also similar with the ones of Videla-Rodríguez

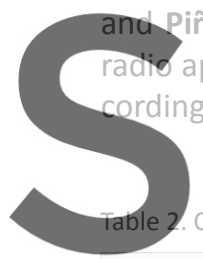

pps, including talk and specia

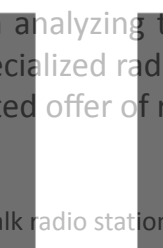

Smartphones

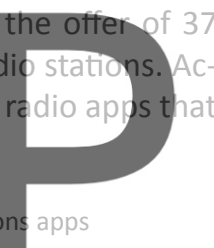

Tablets

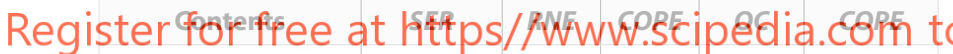

News (in text)

\begin{tabular}{|l|c|c|c|c|c|}
\hline Bulletins & No & Yes & No & No & No \\
\hline Audios & Yes & Yes & Yes & Yes & Yes \\
\hline Scripts & No & No & No & No & No \\
\hline Live radio & No & Yes & Yes & No & Yes \\
\hline Videos (in news) & Yes & No & Yes & Yes & No \\
\hline Pictures/Graphics & (pictures) & No & No & No & No \\
\hline Galleries & Yes & Yes & Yes & Yes & Yes \\
\hline Podcasts & Yes & Yes & Yes & Yes & Yes \\
\hline Programming & Yes & Yes & Yes & Yes & Yes \\
\hline Clips & Yes & Yes & Yes & Yes & Yes \\
\hline Whole programmes & No & No & Yes & Yes & Yes \\
\hline $\begin{array}{l}\text { Access to the Face- } \\
\text { book profile }\end{array}$ & No & No & Yes & Yes & Yes \\
\hline $\begin{array}{l}\text { Access to the Twitter } \\
\text { profile }\end{array}$ & Yes & No & No & No & No \\
\hline The most... & No & No & No & No & No \\
\hline Specials & No & No & No & No & No \\
\hline Premium contents & No & No & No & Yes & Yes \\
\hline External links & No & Yes & Yes & Yes \\
\hline Advertising & Yes & & \\
\hline
\end{tabular}

allow a user-based consumption reveals a very basic introduction of the radio on demand in the fourth screen. This is a common circumstance for almost the entire offer of radio apps, regardless the type of station or the receptor device". Only Radio 1 app allows navigating within the programs and through stations.

\section{In their apps for mobile devices Spanish talk radio stations have content that is mostly text for news, with limited audio clips, videos, pictures, graphs, and exter- nal links}

\section{Personalization
info or enlargi
nor is adjusting
takes advantag
des weather for
to the plavlist,}
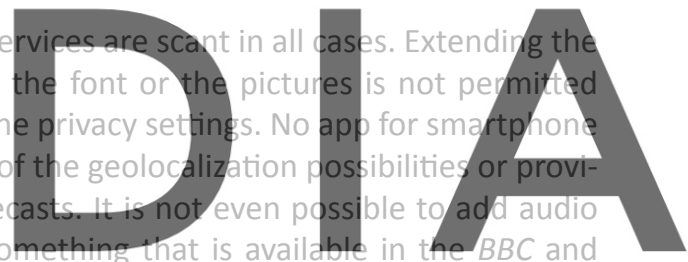

CBC apps

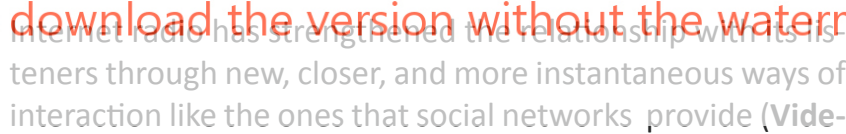
la-Rodríguez; Piñeiro-Otero, 2013a). Thus, communication between station and listeners has become more horizontal because producers and consumers don't play separate roles, but they interact following new rules (Jenkins, 2006; Moreno; Martínez-Costa; Amoedo, 2009). However, results show that possibilities for participation are also meager. All the apps allow the content to be shared through email, messaging services such as Whatsapp, or social networks like Facebook or Twitter. However, none of them allow parti-

Table 3. Usability in the mobile Spanish talk radio stations' apps

\begin{tabular}{|l|c|c|c|c|c|}
\cline { 2 - 6 } \multicolumn{1}{c|}{} & \multicolumn{4}{c|}{ Smartphones } & Tablets \\
\cline { 2 - 6 } \multicolumn{1}{c|}{} & SER & RNE & COPE & OC & COPE \\
\hline $\begin{array}{l}\text { Navigation within the sec- } \\
\text { tions }\end{array}$ & No & No & Yes & No & Yes \\
\hline Changes of section & Yes & Yes & Yes & Yes & Yes \\
\hline Navigation through contents & No & Yes & Yes & No & No \\
\hline $\begin{array}{l}\text { Navigation through pro- } \\
\text { grammes }\end{array}$ & No & Yes & No & No & No \\
\hline Navigation through stations & No & Yes & No & No & No \\
\hline
\end{tabular}


Table 4. Possibilities for personalization in the mobile Spanish talk radio stations' apps

\begin{tabular}{|l|c|c|c|c|c|}
\cline { 2 - 6 } \multicolumn{1}{c|}{} & \multicolumn{4}{c|}{ Smartphones } & Tablets \\
\cline { 2 - 6 } \multicolumn{1}{c|}{} & SER & RNE & COPE & OC & COPE \\
\hline Favorites sections & No & No & No & No & No \\
\hline $\begin{array}{l}\text { Weather forecast personal- } \\
\text { ization }\end{array}$ & No & No & No & No & No \\
\hline Geolocalization & No & No & No & No & Yes \\
\hline To extend the info & No & No & Yes & No & Yes \\
\hline To enlarge image & No & No & No & No & No \\
\hline To enlarge font & No & No & Yes & No & No \\
\hline To adjust the privacy settings & No & No & No & No & No \\
\hline To add to playlist & No & No & No & No & No \\
\hline
\end{tabular}

cipating in polls or sending comments, content, or questions for digital interviews.

With regard to additional services, we can observe the alarm service from Radio 1 and the "Notice me" section in COPE that allow users to receive notifications at the start of previously selected programs. Despite offering additional services and exclusive content is a best practice of leading apps (ex. BBC or NPR), no m
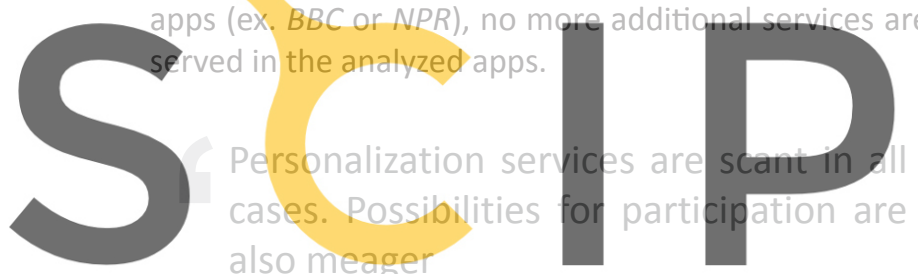

Table 5. Possibilities for participation in the mobile Spanish talk radio stations' apps

\begin{tabular}{|l|c|c|c|c|c|}
\cline { 2 - 5 } \multicolumn{1}{l|}{} & \multicolumn{3}{c|}{ Smartphones } & Tablets \\
\cline { 2 - 6 } \multicolumn{1}{l|}{} & SER & RNE & COPE & OC & COPE \\
\hline $\begin{array}{l}\text { Possibility of adjusting the } \\
\text { volume from the app }\end{array}$ & Yes & Yes & Yes & Yes & No \\
\hline $\begin{array}{l}\text { Possibility of sharing through } \\
\text { email }\end{array}$ & Yes & No & Yes & No & No \\
\hline $\begin{array}{l}\text { Possibility of sharing through } \\
\text { Twitter }\end{array}$ & Yes & Yes & Yes & No & No \\
\hline $\begin{array}{l}\text { Possibility of sharing through } \\
\text { Facebook }\end{array}$ & Yes & Yes & Yes & No & No \\
\hline $\begin{array}{l}\text { Possibility of sharing through } \\
\text { Skype }\end{array}$ & Yes & Yes & Yes & No & No \\
\hline $\begin{array}{l}\text { Possibility of sharing through } \\
\text { Whatsapp }\end{array}$ & Yes & Yes & Yes & No & No \\
\hline Weblog & No & No & No & No & No \\
\hline Chat & No & No & No & No & No \\
\hline Polls & No & No & No & No & No \\
\hline Contests & No & No & No & No & No \\
\hline Comments & No & No & No & No & No \\
\hline Digital interviews & No & No & No & No \\
\hline Send pictures & Yes & No & No & No & No \\
\hline Send other contents & No & No \\
\hline
\end{tabular}
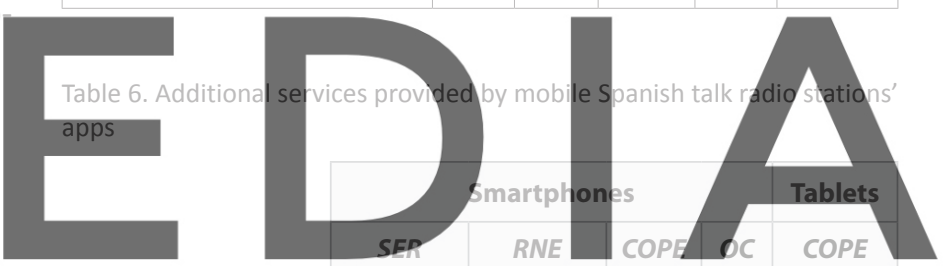

External searcher

No

No

Register for free at https//www.scipedia.com to dowdeleadtche version witbout the matenmark 7. Conclusions

Mobile devices have become the modern version of radio receivers, but radio stations are still working to adapt their content to the new mobile context. From our analysis, we can extract the following conclusions:

- The most popular talk radio stations in Spain have their own apps for smartphones covering iOS and Android, the main operative systems.

- The analyzed apps are identical for iOS and Android. All allow live listening and all are free.

- The only iPad app is for COPE and it is free. The app allows for live listening. Its design is clear and visual.

- Content is mostly composed of text for news, with limited audio, videos, pictures, graphs, and external links. Despite being radio station apps, much of the news does not include audio. Some of the apps offer pictures and only COPE has a section for videos. The text in all apps serves as the main element. Hypertext is underused. All of the apps allow listening or downloading of entire programs and even audio clips. Advertising can be found in four of the five analyzed apps, perhaps as a way of monetizing the product, because the apps freely downloaded.

- Usability is quite poor, having to always return to the main

\begin{tabular}{|l|c|c|c|c|c|}
\hline News library & No & No & No & No & No \\
\hline A la carta & $\begin{array}{c}\text { Yes } \\
\text { (section) }\end{array}$ & $\begin{array}{c}\text { Yes } \\
\text { (section) }\end{array}$ & No & No & No \\
\hline Pastime section & No & No & No & No & No \\
\hline Billboard section & No & No & No & No & No \\
\hline Stock market section & No & No & No & No & No \\
\hline Traffic section & No & No & No & No & No \\
\hline $\begin{array}{l}\text { Book recommenda- } \\
\text { tions }\end{array}$ & No & No & No & No & No \\
\hline Alerts/alarm clock & No & Yes & Yes & No & Yes \\
\hline
\end{tabular}

menu. There are limited options for navigating through sections, content, programs, and stations.

- Possibilities for personalization remain unexplored-something that seems strange when considering that mobile consumption is mostly personal. There are few opportunities to save favorites or playlists. Geolocalization is underutilized as a way to adjust the content or the programming.

- It is only possible to "participate" socially by sharing content through email, Twitter, or Facebook. Neither the smartphone nor the tablet apps allow users to send com- 
ments, pictures, or other content. It is not possible to take part in polls or send questions to an interviewee in a digital interview, etc.

- Finally, we do not find many additional services. None of the apps have a search box -their own or an external one, a tool that can be found in the NPR or BBC apps. Two apps include additional services: Radio 1 has an alarm service and COPE has the "Notice me" section.

- The results allow us to confirm our 3 starting hypotheses: H1) Spanish talk radio stations undervalue the potential of apps for mobile devices and they use them mostly as new channels for distribution and do not consider them autonomous and independent services for a more enriched consumption of radio. The under-use of tools and devices for personalization and participation seems particularly serious coupled with a very poor degree of usability

$\mathrm{H} 2$ ) Except for Radio 1, the remaining anps rarelv include any content that is strictly radio. Text plays a central role in news items, with scant multimedia elements.

H3) Thus far, talk radio stations' apps seem to be mostly web-based, especially considering their content rather than their design.

We can summarize by saying that the most popular Spanish talk radio stations' apps are still in the "adaption
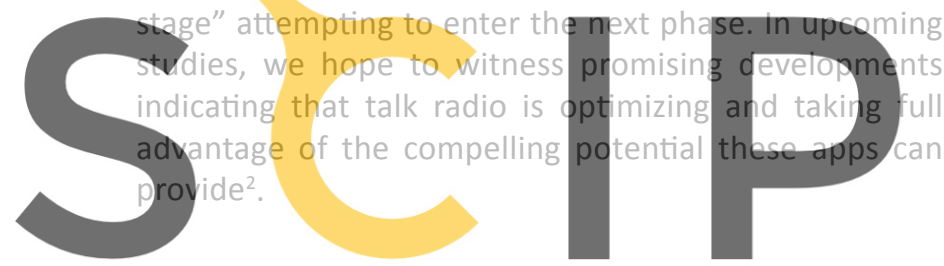

Spanish talk radio stations undervalue

Register for free at bttps/dWWw.scipedia.com to

they use them mostly as channels and

do not consider them as autonomous

and independent services

\section{Note}

1. Results are also in line with those obtained by Cordeiro and Paulo (2014) for the analysis of Portuguese Rádio Comercial and RFM apps. The authors acknowledge the efforts made by radio stations, but they add that it would be desirable to make some improvements by updating with more content, interactivity, and customization.

2. For instance, on May, 12, four months after our data collection, Cadena SER presented its new app. It includes improvements in its design and navigation, multimedia contents, streaming service, alarm clock, live listening to more than 100 Cadena SER's local stations and more personalization options when saving the podcasts. It also offers up-to-date news and the possibility to share contents on social networks such as Facebook or Twitter. Still few options to participate, additional services or exclusive content just for the app.

\section{References}

Aguado, Juan-Miguel; Martínez, Inmaculada (2008). "La comunicación móvil en el ecosistema informativo: de las alertas SMS al mobile 2.0". Trípodos, n. 23, pp. 107-118.

http://www.raco.cat/index.php/Tripodos/article/ download/118915/154119

Arbitron (2012). "The infinite dial 2013: navigating digital platforms". Edison research, April 2.

http://www.edisonresearch.com/the-infinite-dial-2013navigating-digital-platforms

Arroyo-Vázquez, Natalia (2012). Información en el móvil, Barcelona: EPI-UOC, colección El profesional de la información. ISBN: 9788490298473

Canavilhas, João (2009). "Contenidos informativos para móviles: estudio de aplicaciones para iPhone". Textual \& visual media, v. 2, pp. 61-80.

httn://w/M/Mocc ubi.nt/nag/canavilhas-ioao-contenidosinformativos-para-moviles.pdf

Cebrián-Herreros, Mariano (2008). "Radio y convergencia tecnológica en Europa. Expansión de los cibermedios fijos y móviles". En: Ortega, Leopoldo (comp.). Memorias de la 7ạ Bienal internacional de Radio México. Colonia del Valle: Radio Educación, pp. 69-88.

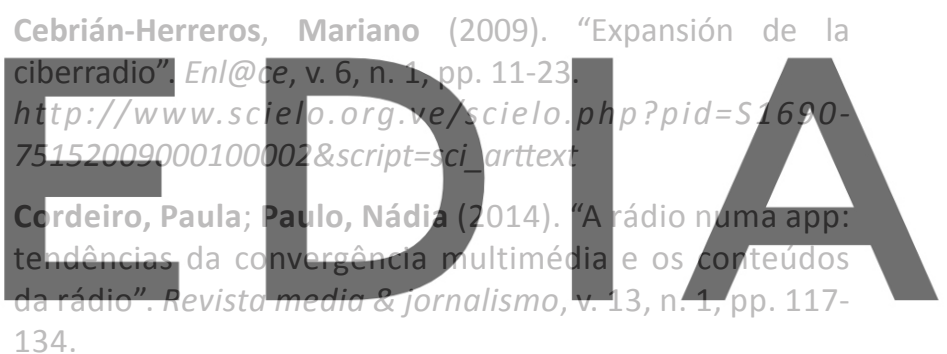

134

\section{drow}

Chyi, Hsiang-Iris; Chadha, Monica (2012). "News on new devices". Journalism practice, v. 6, n. 4, p.p. 431-449. http://dx.doi.org/10.1080/17512786.2011.629125

comscore (2012). "Mobilens: Smartphone penetration reaches 55 percent in October 2012". $h t t p: / / g o o . g l / j 2 j 8 b P$

Del-Bianco, Nelia R. (2010). “O futuro do rádio no cenário da convergência frente às incertazas quanto aos modelos de transmissão digital". Revista de economía política de las tecnologías de la información y comunicación, v. 12, n. 1, pp. 1-19.

http://repositorio.unb.br/bitstream/10482/12282/1/ ARTIGO_FuturoRadioCenario.pdf

Fidler, Roger (1997). Mediamorphosis: Understanding new media. Thousand Oaks: Pine Forge Press. ISBN: 978 0803990869

Fundación Telefónica (2013). Society of information report 2013. http://www.fundaciontelefonica.com/arte_cultura/ sociedad-de-la-informacion/sie2013

Fundación Telefónica (2014). Society of information report 2014. 
http://www.fundaciontelefonica.com/arte_cultura/sociedadde-la-informacion/informe-sociedad-de-la-informacion-enespana-2014

Gartner (2012). Market share: Mobile devices, Worldwide, 1 Q12. https://www.gartner.com/doc/2015915/market-sharemobile-devices-worldwide

Gartner (2013). "Gartner says worldwide PC, tablet and mobile phone combined shipments to reach 2.4 billion units in 2013". Gartner newsroom, April 4.

http://www.gartner.com/newsroom/id/2408515

Gatner (2013). “Gartner says by 2016, more than 50 percent of mobile apps deployed will be hybrid". Gartner newsroom, February 4.

http://www.gartner.com/newsroom/id/2324917

Jenkins, Henry (2006). Convergence culture: Where old and new media collide, New York: NYU Press. ISBN: 978 0814742952

Mitchell, Amy; Rosenstiel, Tom; Houston Santhanam, Laura; Christian, Leah (2012). "The future of mobile news". Pew Research Centre- Journalism \& media

http://www.journalism.org/analysis_report/future mobile news

Moreno, Elsa; Martínez-Costa, Pilar; Amoedo, Avelino (2009). "Radio and the Web: Communication strategies of Spanish radio networks on the Web (2006-

http://www obs.obercom

download/288/278

François; Westlund, Oscar (2012) Journalism practice, $v$
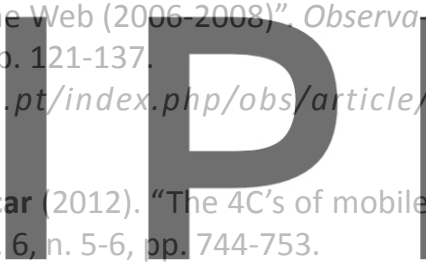

italianas y españolas", Estudios sobre el mensaje periodístico, v. 18, pp. 639-648.

http://revistas.ucm.es/index.php/ESMP/article/view/40943

Ortiz-Sobrino, Miguel-Ángel (2012). "Radio y postradio en España: una cohabitación necesaria y posible". Área abierta, v. 12 , n. 2, pp. 1-16.

http://revistas.ucm.es/index.php/ARAB/article/view/39637

The App Date (2012). "Informe sobre apps en España. Tercer cuatrimestre de 2012". Madrid The App Date, 24 marzo.

http://madrid.theappdate.com

Videla-Rodríguez, José-Juan; Piñeiro-Otero, Teresa (2012). "Apps de radio. Movilidad para un medio radiofónico sin límites". Prisma.com, v. 17, pp. 1-7

http://revistas.ua.pt/index.php/prismacom/article/ viewFile/2020/pdf

Videla-Rodríguez, José-Juan; Piñeiro-Otero, Teresa (2013a). "La radio móvil en España. Tendencias actuales en las apps para dispositivos móviles". Palabra clave, v. 16, n. 1, pp. 129153.

http://palabraclave.unisabana.edu.co/index.php/ palabraclave/article/view/2579/3085

Videla-Rodríguez, José-Juan; Piñeiro-Otero, Teresa (2013b). "Hacia una radio social. Interacción, proyección y repercusión de las cadenas españolas en redes sociales". Icono14, v.

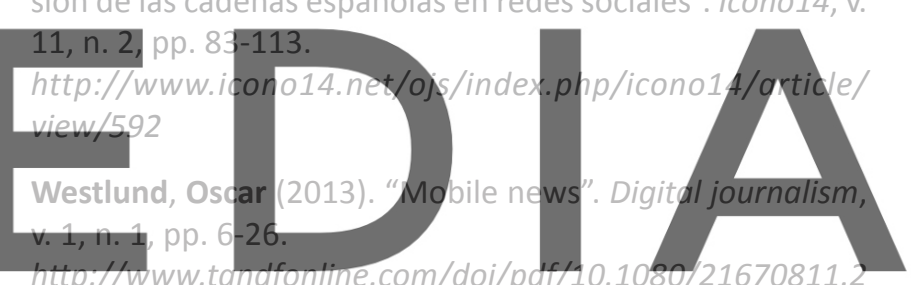

Nozal-Cantarero, Teresa; González-Neira, Ana (2012). “La 012.740273

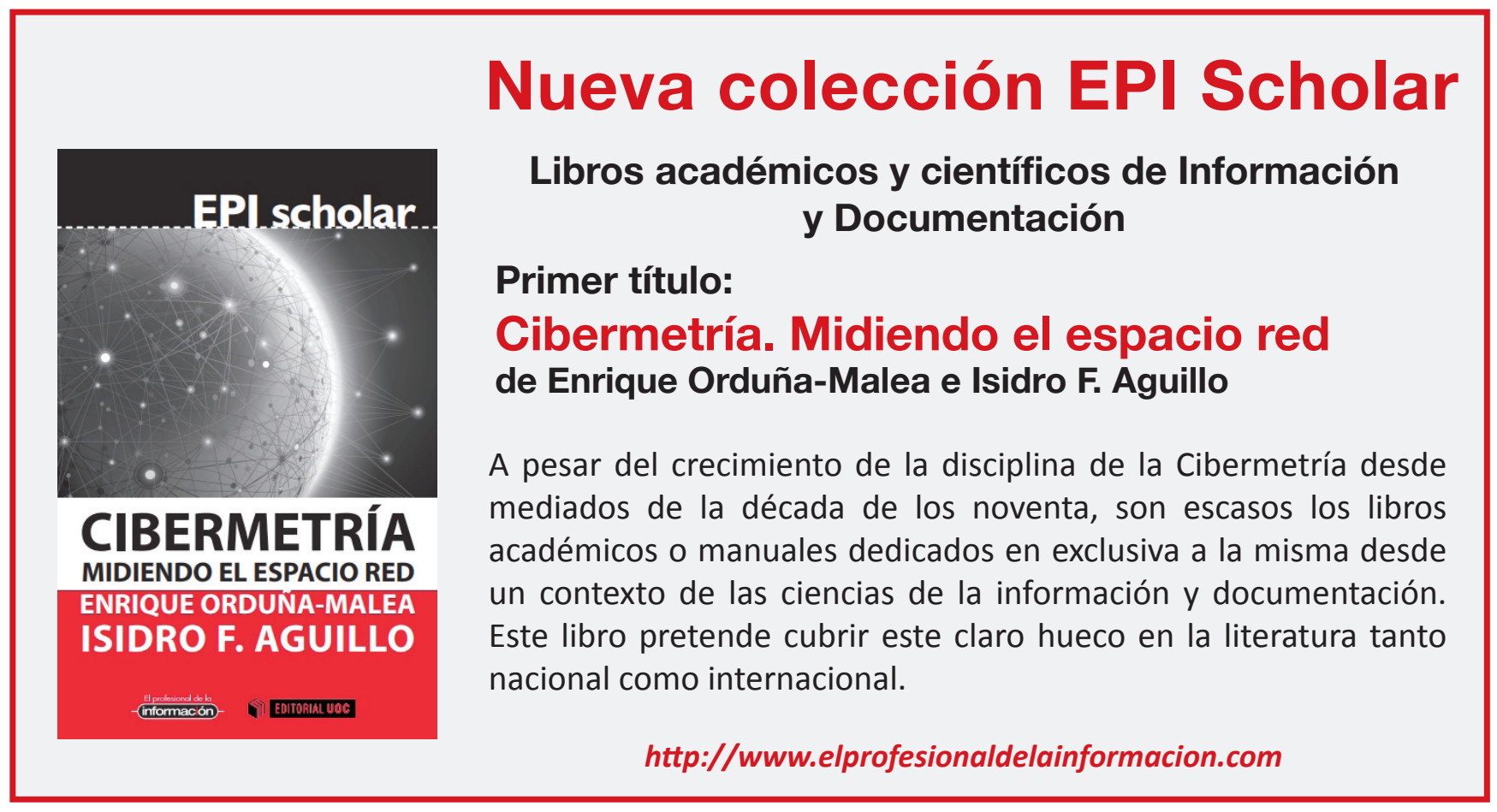

